\title{
Promoting and practicing religious pluralism: Muhammadiyah experience
}

\author{
Biyanto Biyanto
}

Department Theology and Islamic Philosophy, Ushuluddin and Philosophy Faculty, State Islamic University Sunan Ampel Surabaya, Indonesia

Email: mrbiyanto@gmail.com

\begin{abstract}
This article aims to discuss about the experiences of Muhammadiyah in promoting and practicing values of religious pluralism in Indonesia. As one of the biggest modern Islamic organization in the world Muhammadiyah showed to take action in promoting values of religious pluralism. It was showed by education, preaching, social welfare, inter-faith dialogue and peace, and across culture, ethnic, and religious programs. For example, Muhammadiyah formed many schools and universities at all provinces in Indonesia. The network of Muhammadiyah's schools and universities through in districts, in fact at villages. By education, Muhammadiyah taught and practiced values of religious pluralism. It was showed, particularly, by Muhammadiyah's schools and universities at Muslim minority provinces. Province of Papua, West Papua, and East Nusa Tenggara, for example, percentage non-Muslim students and teacher at Muhammadiyah's schools and universities through 75\%-90\%. Muhammadiyah also invited non-Muslim teachers to teach religion. Muhammadiyah gave freedom for every student to practice his religious teaching. By preaching, Muhammadiyah gave an emphasis that the diversity or plurality in the human life patterns is God's wish and a scientific fact (natural of law, sunnatullah). Therefor everyone must celebrate and respect to diversity or plurality. Until
\end{abstract}


now Muhammadiyah still active inter-faith dialogue and peace with religious leaders in Indonesia, even in the world. Muhammadiyah also does programs to against terrorism. The leaders of Muhammadiyah also involved peace building programs ini the world. Promoting values of religious pluralism by Muhammadiyah is very important because Indonesia is a multicultural state in ethnic, culture, and religion.

Keywords: Diversity, Values of Religious Pluralism, Muhammadiyah Experience

\section{Introduction}

One of the themes raised by many Moslem thinkers in the contemporary era, as said Charles Kurzman, is rights of non-Muslim. This theme is very relevant with religious pluralism discourse. The other themes are against theocracy, democracy, rights of women, freedom of thought, and progress. (Kurzman, 1998). Theme of religious pluralism is generally discussed in the context of inter-religious ummah and inter-school of thoughts in a religion. Based on this thought, the religious pluralism discourse had actually appeared during the beginning era of Islam development, especially when the process of conquest (al-futuhat) by the Muslim over non-Muslim ummah happened. The interaction among the ummah of Islam in the period got some sharia legitimation, meaning that the non-Muslims rights, especially Jews and Christians in performing their religion teachings were assured as long as they gave loyalty and paid tributes to the ruling Islam leaders. This fact of history shows that since the beginning, some awareness among the circles of the Islam leaders have appeared in order to build a harmonious life order above the cultural, tribal, and religious plurality.

In the context of the Muslim elites in Indonesia, the religious pluralism discourse has also been much discussed. Especially, the Council of Indonesian Ulama (Majelis Ulama Indonesia, MUI) in its seventh national meeting held on July 26-29, 2005, issued a fatwa (a binding ruling in religious matters) on the deviation to the secularism, pluralism, and liberalism. These three views in the MUI's perspective and their critics are called "Sipilis". Pluralism the MUI has been considered as deviation is the view seeing that all religions are the same (Hasyim, 2015). Even, some figures of social and religious organizations also variously responded to the issue of the religious pluralism. Among them, some support and some reject the fatwa. Whereas Indonesia is multicultural 
state. Indonesia has more than 17.000 islands. There are over 300 ethnic groups and more than 700 living languages spoken in Indonesia. Plurality of society also is shown in religion. There are many religions in Indonesia.

As plural state, why Indonesia is able to keep diversity. Because, Indonesia has national ideology, namely Pancasila (Five Basic Principles). The substance of five principles of Pancasila are: (1) Belief in the one and only God, (2) humanity, (3) unity, (4) deliberative consensus, and (5) social justice. In Pancasila there is national motto, "Unity in Diversity" (Bhinneka Tunggal $I k a)$. Indonesia also has many religious organizations as pillars of civil society, one of them Muhammadiyah. Muhammadiyah is one of the biggest modern Islamic organizations in Indonesia. Muhammadiyah has positively responded to the religious pluralism discourse. It states that plurality is a fact, even, a part of the God's design. Therefore, earthing the religious pluralism values is a necessity. Figures such as Ahmad Syafii Maarif (born, 1935), Din Syamsuddin (born, 1958), Amin Abdullah (born, 1953), Haedar Nashir (born, 1958), Abdul Munir Mulkhan (born, 1946), and Moeslim Abdurrahman (1948-2012), may be called to represent the groups of the Muhammadiyah thinkers who really appreciate the idea of the religious pluralism. Therefore, the aim of this writing is to describe some experiences from Muhammadiyah in promoting and practicing values of religious pluralism in Indonesia.

\section{Literature Review}

Besides religious pluralism, there are also various terms used in some literatures to show the diversity phenomenon in religiousness. The figures such as Richard Huges Seager (Seager, 1993), Thomas Dean (Dean, 1995), and Kosuke Koyama (Koyama, 2016), are those who make use of the term religious diversity (Parsons, 1993). Such various uses show that pluralism has been one of the themes that have been discussed by a lot of inter-religious thinkers. Therefore, it is not exaggerated when Harold Coward states that pluralism is a challenge each religion faces at present. Even, referring to the religiousness tradition, each religion turns out having various doctrines and experiences in facing the pluralism problem (Coward, 1985). Thus, pluralism means that a religion cannot close itself anymore and consider that its teachings and the ritual system are the most valid ones.

In this present context, the discourse of pluralism is not only discussed in terms of the reality of the diverse and complex society, consisting of 
various races and religions, but also in the context of building some genuine engagement of diversities within the bounds of civility. Even, it can be said that pluralism is a necessity for saving the human beings that may be made among others through the mechanism of supervising and balancing among any groups in the society. It means that this perspective places pluralism as a religious typology which is the further stage of inclusivism. Inclusivism necessitates an understanding that other religions possess similarities so that there is a desire to have a meeting point among the religions. Different from inclusivism, pluralism exactly recognizes the differences (Misrawi, 2007).

It is in this context that pluralism may be considered as a continuance from inclusivism since it sees each religion possess a unique reality. Then, here pluralism is present to build some tolerance amid the religious differences and diversities. The problem of diversity is not only experienced by Islam, but also realized by other religions. Therefore, Harold Coward states that pluralism may actually be found out in each religion. According to Harold, great religions, Judaism, Christianity, Islam, Hinduism, and Buddhism, clearly have normative teachings and historical experiences in facing the society's plurality problem (Coward, 1985). But, in John Hick's perspective, Islam seems to have a clear view on pluralism. According to John Hick (19222012), it is because Islam has a doctrine on the scribers (ahl al-kitab) covering Judaism and Christianity (Hick, 1989: 197-199). Among the thinkers of Islam, the discourse of the scribers is also debated so that this issue seems to be controversial.

So, how the elit groups of Muhammadiyah respond to religious pluralism? One of them, Kuntowijoyo (1943-2005) said that pluralism may be typified into two, negative and positive pluralism (Kuntowijoyo, 2001: 287). The term "negative pluralism" is used to show one's very extreme religious attitude. This extreme attitude for example is shown by statement that a religion is like to wear clothing so that one may replace it any time with another. In the mind of the conceivers and builders of this negative pluralism, they acknowledge that there are many religions. Principally, this statement is in line with the existing reality. But stating that a conversion of religion naturally happens as easily as replacing clothing of course may result in some controversies. Pluralism is said to be negative if there is someone viewing that it is not necessary to hold his religious faith firmly.

Meanwhile, positive pluralism is a religious attitude respecting to the opinions, ways of life and faiths. When explaining this positive pluralism, 
Kuntowijoyo exemplified his own experiences when he was studying abroad. For instance, when there was an announcement of a beer party, he came to the party by bringing coca cola with him. If he found out that his friend living in the same apartment with him was addicted to beer, he was willing to accompany him to come to a restaurant to buy beer. Even, when asked whether his refrigerator may be used to store beer, he answered "yes" as long as he was not asked to drink beer. It turns out that America which is very plurality in the human life patterns according to Kuntowijoyo still give opportunities to the development of this positive pluralism (Kuntowijoyo, 2001).

Meanwhile, Nurcholish Madjid (1939-2005) gives an emphasis that the diversity or plurality in the human life patterns is God's wish and a scientific fact. According to Nurcholish, pluralism is a value system requiring human beings to respect forms of plurality by accepting plurality as a reality and then doing some kindness in accordance with each personal disposition (Madjid, 1992). In this context, Nurcholish suggests that the ummah of Islam applies a principle called an internal relativism principle. The character of this internal relativism according Nurcholish may be used as a way out for the ummah avoid an absolutism claim for oneself and his own group. This principle is stated by Nurcholish in the context of building Muslim Brotherhood (Ukhuwah Islamiyah) in Indonesia (Madjid, 2000).

It is through the brotherhood spirit that one should change any differences into a positive base of the life attitude, such as doing a race for goodness (al-khairat). This condition may be realized if an attitude of respecting and appreciating any differences among the members of the society grows well. According to Nurcholish, Indonesia possessing the greatest amount of Muslims in the world may offer itself as a lab for developing religious tolerance and pluralism. Besides, the ummah of Islam in Indonesia is trying hard to bring Islam into positive and constructive dialogues in line with various demands of places and time. Nurcholish also uses some verses of the Holy Qur'an as a base to build pluralism values (QS. al-Hujurat/49: 11-13).

The law of difference according to Nurcholish is God's determination for human beings. Even, the law also prevails for those with each biographical, social, and cultural background believing in God. Therefore, brotherhood based on belief (ukhuwah imaniyah) under a diversity framework is really suggested by Allah SWT (QS. al-Hujurat/49: 10). Since difference is God's determination, each person should be really (ijtihad) trying to look for, to understand, and to catch the truth. Nurcholish, citing Ibn Taymiyah (1263. 
1328) states that those who are doing ijtihad cannot be blamed, since if their ijtihads are right, they will get multiple rewards from God. Whereas, if their ijtihad is wrong, they will still get the reward, although the reward is just one. Therefore, the freedom of thinking, of speech, and of gathering without any suspicion among groups of society should always be maintained.

A scientist, who is also called the Father of Comparative Religion in Indonesia, Abdul Mukti Ali (1923-2004), also proposes a typology of the religious pluralism. According to Mukti Ali, plurality is a reality which is clearly seen. In Indonesia, many religions may also be found out. Even, there are six official religions in Indonesia, namely Islam, Christian, Catholic, Hinduism, Buddhism, and Confusius. Each religion must teach different ways of life. It is the believer's faith to understand God's teaching. Since Indonesian people live in a plural society, a way towards harmony in religious life is needed.

Moreover, Mukti Ali shows some choices that may be proposed to grow the religious pluralism values. First, there is an opinion stating that all religions are the same. It is called "syncretism". This syncretic pattern grows well not only in Indonesia but also in some other developing countries. In Indonesia, the syncretism becomes the main teaching of mystical groups. In the 1959 report of Badan Kongres Kebatinan (Mystical Congress Board), it is formulized that all conceptions of God are the aspects of the one Supreme, eternal, and unending God. All religions are aspects of a great way into one truth. This formula shows one of the pillars of the syncretic group's teaching.

The second pattern is called re-conception, meaning seeing through and reviewing one's religion in relation to others. This pattern requires an arrangement of a universal religion that fulfills all people and nations' needs by way of re-conception. This way is reached by stating that each person should believe in his own religion, but in each religion, one should enter elements of other religion into his own religion.

The third pattern is synthesis, meaning creating a new religion of which its elements are taken from various religions. It is done in order to make each believer feels that some of his religion teaching has been represented in the synthetic religion. By this way, each believer hopes that he may have a harmonious and peaceful life.

The fourth pattern is replacement, meaning that it is one's religion that is right, while others are wrong. Therefore, there will be some efforts that other believers should enter into one's religion. He is not willing if there are 
other persons believing in different religions and faiths. Consequently, other religions should also be replaced with the religion one believes in order to create a harmonious life.

The fifth pattern is called agree in disagreement. This patter teaches that it is the religion one believes in is the best. But he lets other people believe that their religions are the best. This typology also teaches that each religion has differences and sameness. So, an attitude to grow in this matter is to respect one another among religion believers (Ali, 1992).

From the alternatives, Mukti Ali states that the agree in disagreement pattern is the most relevant for each believer. It is said that a religious person should believe that it is the religion one believes in is the best and the most right. And, others are let, or appreciated to believe the truth of the religion one believes in.

Another typology of pluralism is also proposed by Diana L. Eck (born, 1945), Professor of Comparative Religion and Indian Studies at Harvard University. According to Diana, a religious pluralism possesses four important characteristics; first, pluralism is not diversity alone, but the energetic engagement with diversity. A religious diversity is something given, while a religious pluralism is an achievement that should always be actively tried. Second, pluralism is not just tolerance, but the active seeking of understanding a cross lines of difference. Third, pluralism is not relativism, but the encounter of commitments. Fourth, pluralism is based on dialogue. Dialogue means involvement of two or more persons to speak and to listen to. Both are in a process to open their mind on the sameness of understanding and the reality of difference (Eck, 1993). Hence, what is important in this dialogue is the existence of commitments and willingness to share, to criticize and to be criticized.

\section{Methods}

The method of this study was a literature review or library research. The data was collected with reading the books, the paths of the books, articles in journals, sources from the websites, and documents of Muhammadiyah. This study used the qualitative approach. According Lawrence Neuman that qualitative style had some characteristics: (a) construct social reality, cultural meaning; (b) focus on interactive processes, events; (c) authenticity is key; (d) values are present and explicit; (d) situationally constrained; (e) few cases, subjects; (f) thematic analysis; and (g) researcher is involved (Neuman, 2003). By 
Qualitative approach as Neuman said this study described the meaning of the views of Muhammadiyah about promoting and practicing religious pluralism in Indonesia.

\section{Results and Discussion}

One of the Muhammadiyah important works dealing with the idea of religious pluralism is a book published by Majelis Tarjih dan Pengembangan Pemikiran Islam with the title of Tafsir Tematik al-Qur'an tentang Hubungan Sosial Antar Umat Beragama (Thematic Interpretation of the Holy Qur'an on The Social Relationship Among Religious Ummah) (henceforth, Tafsir Tematik) (Abdullah, 2000). This is important since the theme of the actual social relationship among religious ummah is discussed. It is because there are many cases of intolerance among religious ummah. Indonesia during the post reform era is also colored with various cases of radicalism with religion nuances. Even, there are suicide bombing in various areas. Muhammadiyah as one the the greatest social religious organizations in this country clearly should give some positive contributions.

As a whole, the Tafsir Tematik consists of four parts. The first part the discussion of the principles of the relationship among religious ummah. In this part, an interpretation on a number of verses that may be understood as the recognition of Islam to the fact of the religion diversity is presented. A commitment to realize a peaceful coexistence in the relation among religious ummah also exists. The second part talks about how to maintain good relations and cooperation among religious ummah. The third part is the discussion of the Holy Qur'an on the scribers. The last part discusses about marriages between brides and bridegrooms possessing different religions according to the Holly Qur'an. Some discourses developed in the Tafsir Tematik should be appreciated because it is relevant with the problems of pluralism in the contemporary era, especially in Indonesia.

The explanation of the religious pluralism and of the response to it is discussed at the first part of the book. It is said that pluralism in the study of theology possesses three interpretations. First pluralism means a fact that the religious ummah is plural. In the context, pluralism means actual plurality, especially the Indonesian government recognizes many religions and faiths.

Second, pluralism has a political connotation of which the meaning is synonymous with secularism. In this case, secularism may have two meanings; 
(1) separating religion from public affairs and also reflecting an anti-religion phenomenon, (2) the state that does not identify itself to a certain religion, but that respects and gives opportunities to all religions to develop. The policy made by the Indonesian government on the existence of religions reflects the development of secularism under the second meaning. Third, the term plurality refers to a view stating that all religions at last lead towards one same truth (Abdullah, 2000).

As one pillar of the civil society, Muhammadiyah is committed to present the feature of modern plurality. The face of Indonesian Islam should be brought toward a moderate form. This awareness may be observed through actions Muhammadiyah has done in the recent years. In the Tanwir meeting held in Yogyakarta, dated from April 26-29, 2007, some problems dealing with the nationality roles of Muhammadiyah, including its contribution to the development of the democratic cultures, human rights, environment, and cultural plurality were discussed. In its $47^{\text {th }}$ Congress held in Makassar, dated on August 3-7, 2015, a concept of Pancasila state as a consensus of all elements of the nation was also formulized. The form of Indonesia state is considered to be final. For Muhammadiyah, it is high time for us to fill in this country with crediting achievements.

According to one of its figures, Abdul Malik Fadjar (born, 1939), Muhammadiyah actually has a normative reference to lead its members to do their lives under pluralistically geographical and cultural environment (Fadjar, 2007). The base Malik Fajar said is a smart book serving as a guide to do daily lives. The book is Pedoman Hidup Islami Warga Muhammadiyah (An Islamic Life Guide for the Members of Muhammadiyah). This book has discussed the life of family, society, and state, environment preservation, and the life of the art, and culture.

Another figure, Sudibyo Markus, states that the nationality roles of Muhammadiyah actually may be observed since the establishment of this organization. Many of its activities have been directed to the fields of missionary endeavors, education, health and social welfare that directly deal with the life of society, nation and state (Markus, 2007). Although Alwi Shihab (born, 1946) in his research states that one of the factors of the birth of Muhammadiyah is to dam up the flow of Christianization, but it does not mean that Muhammadiyah does not respect the religious and cultural plurality. Various dialogues made by the founding father of Muhammadiyah, KH Ahmad Dahlan (1868-1923), with a number of Christian missionaries 
show commitments of the founding father to build a more dialogical interreligion relationship.

From the beginning, not only has Muhammadiyah made inter-religion associations, but also shown a very open organization. The relationship between Muhammadiyah and Budi Utomo, an organization pioneering the national resurrection with "nationalism-Java" ideology shows the openness character. A good relationship with Budi Utomo was also shown through the willingness of this organization to invite Ahmad Dahlan to give a speech in front of the Congress participants in 1917. The participants were so interested in the speech that some of them asked him to give lectures on religion and also to open branches of Muhammadiyah in their regions. As a result, it is not surprising that in 1920, Muhammadiyah had succeeded in reaching areas all over Java Island (Arifin, 1990).

Beside maintaining good relationships with religious organizations such as sufi order (tarekat) in Islam, Muhammadiyah are also open with non religious organizations. Even, with a communist-bowed organization such as ISDV (Indische Social Demochratische Vereeniging), Muhammadiyah also built a good relation. It was proved by the fact that Ahmad Dahlan also invited the figures of ISDV and chairman of the Communist Party of Indonesia such as Semaun (1899-1971) and Darsono (born, 1897) to give speeches in the Open Meeting of Muhammadiyah held in Kauman, Yogyakarta (Arifin, 1990). The facts show that Muhammadiyah whishes to develop a culture of inter-ethnic and religion dialogues. This shows the basic character of Muhammadiyah, open to plurality.

At present, Muhammadiyah is also trying to develop an openness culture. The spirit of openness certainly will be meaningful to its members, especially those who live in minority areas. Sudibyo told that there are some Muhammadiyah schools located in the Christian majority areas such as East Nusa Tenggara, West Papua, and Papua. There are many Christian students in Muhammadiyah schools at that provinces. Therefore, there is a joke that "there are many pastors who are alumni of Muhammadiyah schools." It is because $75-90 \%$ of the students in the Muhammadiyah schools and universities are Christians. The interesting, Muhammadiyah always invite the Christianity teacher to teach Christian students. The phenomenon shows the basic character of Muhammadiyah, has open attitudes and respects cultural and religious diversity.

Some efforts to build inter-religious, ethnic, and cultural relationships 
have always been being made by Muhammadiyah up to now. Pioneering spirit of Muhammadiyah in various international multicultural forums such as World Peace Forum (WPF), Asian Committee on Religions and Peace (ACRP), and World Committee on Religions and Peace (WCRP), shows strong whishes of Muhammadiyah to earth religious pluralism values. Din Syamsuddin (Head of Central Board Muhammadiyah in 2005-2015) still has occupied the presidents of WPF, ACRP, and WCRP. Din states that the institutions he leads have members of leaders, thinkers, religious elites, and scholars from all over the world (Sukma, 2006).

Periodically, Muhammadiyah and WPF also make joint programs. One of them is an activity made in August, 2006 with the theme; One Humanity, One Destiny, One Responsibility. The theme was chosen to respond the world condition full of wars, conflicts, and violences. In 2012, the fourth WPF meeting with the theme of Consolidating Multicultural Democracy was held. This meeting shows the actions taken by Muhammadiyah in consolidating multicultural democracy so that an inter-ethnic, cultural and religious dialogical relationship may be maintained. Actions taken by the youth of Muhammadiyah to earth the religious pluralism values are also seen through NGOs such as Maarif Institute for Humanity and Culture, Youth Intellectual Network of Muhammadiyah (Jaringan Intelektual Muda Muhammadiyah, JIMM), al-Maun Foundation, and Center for Dialogue and Cooperation among Civilization (CDCC).

Maarif Institute may be said to be an embryo of almost all NGOs with the bases of the youth of Muhammadiyah. Maarif Institute was established in 2002, when Ahmad Syafii Maarif became the General Head of Central Leader of Muhammadiyah. Beside Syafii Maarif, there are popular figures as the founders of Maarif Institute such as Haedar Nashir, Moeslim Abdurrahman, Jeffrie Geofannie (born, 1967), Rizal Sukma (born, 1964), and Suyoto (born, 1965). In the statute of the establishment it is stated that Maarif Institute is committed to the cultural movements in the Islam, humanity, and Indonesia context. Some contemporary issues dealing with humanity problems such human rights, pluralism, gender, and inter-religion and civilization dialogues become the concern of Maarif Institute. Today, Muhammadiyah active interfaith dialogue and peace with religious leaders in Indonesia, even in the world. Muhammadiyah also does programs to against terrorism and radicalism.

Under leadership Haedar Nashir and Abdul Mukti, Muhammadiyah proposed programs for strengthening of religious moderation (wasatiyyah 
Islam) to replace deradicalization that be done by government. Muhammadiyah also involved actively peace building programs in the world, for example in South Thailand, South Philippines, and Myanmar. At the world level Muhammadiyah has partnered with international institutions such as USAID, AusAID, Muslim AID, UNICEF, Bill \& Melinda Gate, Community of Sant'Egidio, Global Fund, and the Asian Muslim Charity Foundation (Biyanto, 2020). All partnerships are generally in the form of support for humanitarian work to help those who were victims natural and humanitarian disasters. Muhammadiyah helped them regardless of religion and ethnicity.

\section{Conclusion}

Various activities Muhammadiyah has held show its commitment to present moderate and friendly face of Islam about religious and cultural plurality. Efforts to earth religious pluralism values have been made through the field of education, beside the actions taken by the figures of Muhammadiyah. The educational institutions of Muhammadiyah from the elementary, secondary to tertiary levels have maximized its roles as public services to educate the children from various ethnic groups, classes, and religions. The actions Muhammadiyah has taken in this field may be felt in areas with Moslem minority. It means, therefore, that Muhammadiyah has positively responded to the plural and multicultural challenges. Muhammadiyah also asks the government and foreign funding agencies to earth pluralism values all the time, and it also has intensified its activities to ask as many as possible individuals, societies, and institutions to present developed and moderate Islam. All of these show the actions Muhammadiyah taken as a civil society committed to promote religious pluralism values by education, preaching, social welfare, inter-faith dialogue and peace, and across culture, ethnic, and religious programs. Muhammadiyah taught values of religious pluralism with example, not only as knowledge or discourse.

\section{References}

Abdullah, M. A. et.all. (2000). Tafsir tematik al-Qur'an tentang hubungan sosial antarumat beragama. Yogyakarta: Suara Muhammadiyah.

Ali, A. M. (1992). Ilmu perbandingan agama. In Daya, B. \& Beck, H. L. (Eds). Ilmu perbandingan agama di Indonesia dan Belanda. Jakarta: INIS. 
Arifin, MT. (1990). Muhammadiyah potret yang berubah. Surakarta: Institut Gelanggang Pemikiran Filsafat, Sosial Budaya, dan Kependidikan.

Biyanto. (2020, June 12). Ta'awun Muhammadiyah. Republika, 4.

Coward, H. (1985). Pluralism challenge to world religion. Maryknoll, NY: Orbis Books.

Dean, T. (ed). (1995). Religious pluralism and truth: Essays on cultural philosophy of religion. Albany: State University of New York Press.

Eck, Diana L. (1993). What is pluralism. Nieman Reports God in the Newsroom Issue, 47(2), 1-16.

Fadjar, A. M. (2007). Muhammadiyah: Peran kebangsaan, dinamika perkembangan demokrasi, HAM, lingkungan, dan pluralitas budaya. In Materi Tanwir Muhammadiyah. Jakarta: Pimpinan Pusat Muhammadiyah, $87-90$.

Hasyim, S. (2015). Majelis Ulama Indonesia and pluralism in Indonesia. Philosophy Social Criticism, 41(4-5), 487-495. https://doi. org/10.1177\%2F0191453714566547

Hick, J. (1989). Trinity and incarnation in the light of religious pluralism. In Hick, J. \& Meltzer, E. S. (Eds). Three faith one God: A Jewish, Christian, Muslim encounter. Albany: State University of New York Press.

Koyama, K. (2016, July 8). A theological reflection on religious pluralism. In http:// www.findarticles.com/cf_0/m2065/2_51/56063939/print.jhtml.

Kurzman, C. (Ed). (1998). Liberal Islam: A sourcebook. Oxford: Oxford University Press.

Kuntowijoyo. (2001). Muslim tanpa masjid. Bandung: Mizan.

Madjid, N. (1992). Islam doktrin dan peradaban. Jakarta: Paramadina.

Madjid, N. (2000). Masyarakat religius. Jakarta: Paramadina.

Markus, S. (2007). Peran kebangsaan muhammadiyah dan dinamika perkembangan demokrasi, HAM, lingkungan, dan pluralitas budaya. In Materi Tanwir Muhammadiyah. Jakarta: Pimpinan Pusat Muhammadiyah, 91-95.

Misrawi, Z. (2007). Al-Qur'an kitab toleransi. Jakarta: Fitrah dan Perhimpunan Pengembangan Pesantren dan Masyarakat.

Neuman, W. L. (2003). Social research methods: Qualitative and quantitative approaches. Boston: Allyn and Bacon. 
Journal of Social Studies (JSS), Volume 16, Number 2, 2020: 197-210

Parson, G. (Ed). (1993). The growth of religious diversity Britanian from 1945. London: Routledge.

Seager, R. H. (Ed). (1993). The Dawn of Religious Pluralism: Voices from the World Parliament of Religion 1893. Illionis: Open Court Publishing Company.

Sukma, R. et.all. (2006). Report world peace forum: One humanity, one desnity, one responsibility. Jakarta: Bureau for International and Cooperation Central Board of Muhammadiyah 